\title{
LANGUAGE LEARNER AUTONOMY AND LANGUAGE LEARNING OPPORTUNITIES INSIDE AND OUTSIDE CLASSROOM
}

\author{
Hoang Nguyen Thu Trang* \\ VNU University of Languages and International Studies, \\ Pham Van Dong, Cau Giay, Hanoi, Vietnam \\ Received 19 April 2019 \\ Revised 30 May 2019; Accepted 3 June 2019
}

\begin{abstract}
This study aims at investigating the degree of control that non-English major first-year students exercise over their learning processes, resources and contexts in and out of the classroom. Data were obtained from questionnaires with 63 students, 30-to-60-minute interviews with three students, and the researcher's notes of her observation during classroom lessons. The results from quantitative analysis for Mean and frequency and content analysis for emerging themes of the data reveal variation among the learners and withing each learner regarding the degree of their control over their language learning processes and resources in different contexts of learning and using the language. This suggests the need of helping learners to create learning opportunities both inside and outside the classrooms.
\end{abstract}

Keywords: autonomy, language learning processes, resources, contexts

\section{Introduction}

Theoretically speaking, learner autonomy has been a "hot" topic since the appearance of learner centered approach in second language acquisition. Recently, scholars such as Palfreyman and Smith (2003), Benson (1997, 2003), Benson, Chik and Lim (2003), Norton (1995), Norton and Toohey (2002), Toohey and Norton (2003) appear to shift their focuses from technical and psychological aspects onto the cultural, social and political aspects of this concept. However, there are still quite few studies investigating the changes in learners' levels of autonomy across learning contexts. This research is a modest attempt to fill in this gap.

\footnotetext{
Tel.: 84-985526828
}

Email: tranghnpearl@gmail.com
In practice, teaching a "new" honor programme, in which the language learners of whatever language level are expected to show their high employability to difficult employers when graduating from university. This means that in order to be competitive in the severe job markets for big-salary positions, the learners must have the ability to self-direct and control their own learning processes, i.e. they must show a high level of "learner autonomy" (Holec, 1981: 3).

\section{Literature review}

Learner autonomy is also termed as "learner independence", "self-direction", "autonomous learning" or "independent learning" (Palfreyman \& Smith, 2003: 3). For those who follow a learner-centered approach to language learning, the term "autonomy", 
originating in the late 1970s in the West (Lewis \& Vialleton, 2011: 206), is synonymous to "independence" (Palfreyman \& Smith, 2003: 4). For others (e.g. Boud, 1981; Brookfield, 1986) who take the sociocultural viewpoints inspired by Vygotsky (1978) highlight the collaboration of language learners in their learning process for mutual benefits by suggesting the term "interdependence" instead (Palfreyman \& Smith, 2003: 4). Nevertheless, emphasizing the social aspect of language learning, researchers like Norton (1995), Toohey and Norton (2003) prefer the term "agency" to "autonomy" to show that language learners' investment is part of their self-defining.

Accordingly, there are three broad ways of talking about learner autonomy in language education: (1) a 'technical' perspective, emphasizing skills or strategies for unsupervised learning: specific kinds of activity or process such as the 'metacognitive', 'cognitive', 'social' and other strategies identified by Oxford (1990); (2) a 'psychological'perspective, emphasizing broader attitudes and cognitive abilities which enable the learner to take responsibility for his/her own learning; and (3) a 'political' perspective, emphasizing empowerment or emancipation of learners by giving them control over the content and processes of their learning" (Benson, 1997, cited in Palfreyman \& Smith, 2003: 3). Similarly, Oxford (2003) proposes a model of learner autonomy consisting of four perspectives, namely technical perspective focussing on the physical situation; psychological perspective focussing on characteristics of learners; sociocultural perspective focussing on mediated learning; and political-critical perspective focussing on ideologies, access, and power structures (pp. 76-80).
Technically, autonomy is used "for situations in which learners study entirely on their own" (Benson \& Voller, 1997, 1-2); it refers to "the situation in which the learner is totally responsible for the decisions concerned with his/her learning and the implementation of these decisions" (Dickinson, 1987: 11, quoted in Oxford, 2003: 81). This can be seen in the introduction of Farivar and Rahimi's (2015) study about Computer Assisted Language Learning which helps to develop learner autonomy among Iranian students. In traditional classroom conditions, in order to nurture learners' autonomy, Nguyễn Thị Hằng Nga and Nguyễn Ngọc Toàn's (2017) help 30 learners build their intrinsic motivation by letting them choose the topics and develop their own presentations. These two researchers and Nguyễn Thị Hợp (2018) also introduce the economic concept of goal management to a writing class of 21 second-year non-English major learners. The result of their study reveals that by specifying the learning goal of each language lesson, the teacher can reduce the learning stress, create a favourable and active learning environment and help learners build their goal management skills. Thus, the teacher plays a vital role in creating the physical learning conditions which promote learners' initiation and responsibilities for their own language learning. However, such abilities are more thoroughly analysed in the psychological field.

Psychologically, autonomy refers to "a set of skills which can be learned and applied in self-directed learning" (Benson \& Voller, 1997). "Autonomous learners are cast in a new perspective, have a capacity for detachment, critical reflection, and decision-making, take independent actions and are expected to assume greater responsibility for and take charge of their own learning" (Little, 1991: 4, cited in Xhaferi \& Xhaferi, 2011: 150). 
That is, they are well aware of their learning styles and strategies, adventurous, tolerant of ambiguity, and outgoing (Thanasoulas, 2000, cited in Xhaferi \& Xhaferi, 2011: 150). In other words, autonomy refers to learners' capacity to self-plan, monitor and selfevaluate their language learning (Benson, 2001: 47; Benson, 2003: 290; Nunan, 2003: 194; Sinclair, 2000). For instance, a study by Ceylan (2015) shows that the more strategies the students employ, the more autonomous they might become as they start to shoulder the responsibility of their own learning process. Specifically, Xhaferi \& Xhaferi (2011) identify such common autonomydevelopment techniques used by teachers and students of higher education in Macedonia as portfolios and learner diaries. Similarly, the effectiveness of using vocabulary notebooks in boosting learner's control over their study processes is confirmed by Vela and Rushidi (2016) in a group of 90 non-English major students at a university English center. In Vietnam, Đinh Thị Hồng Thu's (2017) survey on the autonomy of students of Chinese major shows that although most of the first year students of Chinese major at the University of Languages and International Studies Vietnam National University Hanoi (ULIS - VNU) are well aware of the necessity of learner autonomy, and although some may plan their own learning, a large majority of the learners cannot set their goals clearly. As to strategies to boost learner autonomy, Lưu Ngọc Lan's (2014) comparison of the viewpoints of 9 teachers and 223 students at ULIS shows a mismatch between the most frequently and effectively used strategies by teachers and those perceived by students. Nevertheless, since language is a means of communication, language learning cannot be regarded as a pure psychological activity. Its social aspect must also be considered.
While psychological perspectives focus on individual learners, "sociocultural perspectives on learner autonomy focus on mediated learning" (Oxford, 2003: 85). For instance, Ismail and Yosof's (2012) study on the use of language learning contracts among 141 first year English as a second language learners highlights the social support in such classroom tasks in creating "a multiplier effect especially on fledgling autonomous learners" (p. 478). Similarly, Benson, Chik and Lim (2003) see autonomy as a sociocultural process through the stories of two successful English learners in Asia. These authors argue that taking culture into consideration, the concept of autonomy should be understood as 'autonomous interdependence' since the language learning process is shaped by the learner's strong sense of both individual identity and cultural identity (Benson, Chik \& Lim 2003). When autonomy is seen as closely related to identity, political perspectives also emerge.

Politically, autonomy can be used "for an inborn capacity which is suppressed by institutional education and for the right of learners to determine the direction of their own learning" (Benson \& Voller, 1997: 1-2, quoted in Nunan, 2003: 193-194). That is, politicalcritical perspectives on learner autonomy focus on power, access, and ideology (Oxford, 2003: 88). A typical example is Toohey and Norton's (2003) case study on the success of an adult and a child language learners. These authors claim that "learning to use the tool of language $[\ldots]$ is primarily a matter of access to skilled performance, practice and access to identities of competence" (p. 71).

Highly aware of the social constraints as well as potential affordances to the language learning process of students inside and outside the classroom, we would like to 
investigate learners' willingness and exercise of control over the learning goals, materials and conditions. Specifically, this study aims to answer the two questions below.

(1) To what extent do the non-English major learners in the honor programme exercise their control over the learning processes, resources and classroom language learning contexts?

(2) To what extent do these learners exercise their control over the language learning processes, resources and out-of-class language using contexts?

\section{Methodology}

\subsection{Participants}

This study was carried out in one academic year, with the participation of 63 first-year students majoring in Finance and Banking and Business Administration in the first semester and 20 students of the latter major in the second semester. Though they were at different levels of English proficiency, they were all expected to get CEFR B2 levels in order to learn some of their majors in English in the following academic years. Their English courses are IELTS-oriented.

\subsection{Data and data collection}

The data were obtained from two questionnaires basing on our interpretation of the term learner autonomy as mentioned above as well as Brookfield's (1990: 32) experiencing learning questionnaire and Wen's (2004: 360-363) language learner factors questionnaire, and in-depth semi-structured interviews lasting from 30 to 60 minutes with three students (whose pseudonyms are Kim, Anh, Tan), and teacher observation and reflection during one academic year. The questionnaires, a common data collection method (Nunan, 2001), were used because of their advantages in time and money saving, objectiveness and "straightforward analysis of answers to closed questions" (Gillham, 2000: 6). The first questionnaire (at the end of the first semester, answered by 63 students) mainly focused on students' reflection on their own classroom learning like their needs for language knowledge and skills. The second questionnaire (at the end of the second semester, delivered to 20 students) focused on their reflection on their language learning process and their expectations for the future use of the target language. This time, all the questions were open-ended in order to reach "a greater level of discovery" (Gillham, 2000a: 5).

After that, three semi-structured interviews were carried out to detect and correct any possible misunderstandings (Gillham, 2000b: 10). The first interview with Kim was carried out in Vietnamese over lunch in a public, but not too noisy, place to make her comfortable. The next one with Tan was conducted after a speaking test as Tan was the last person to sit the test, and he was willing to answer the interview in English for 30 minutes. The last one, lasting nearly 30 minutes, was initiated by Anh in a revision session while the students were asked to look through the course themselves and raise their questions for the teacher. The teacher took notes during the interviews to make the interviewees relaxed and feel free to speak out their memories, thoughts, and opinions (Richards, 2003).

\subsection{Data analysis}

The students' answers to closed-ended questions in the first questionnaire were counted and summarised in tables and charts. 
Their answers to open-ended questions and in the interviews as well as the teacher's notes were examined for "emergent patterns and theme, by looking for anything pertinent to the research question" (Mackey \& Gass, $2005,241)$. The repetition of such themes is also counted for frequency.

\section{Results}

\subsection{Learner control of language learning} processes, resources and classroom language learning contexts

\subsubsection{Learner self-assessment of their} learning processes

The first part of the first questionnaire, consisting of 4 questions, aims at finding out learners' evaluation on their language learning in class during the foundation phase. These questions were built on the basis of our interpretation of the term autonomy as "the exercise of learners' responsibility for their own learning" (Benson \& Voller, 1997: 1 - 2, quoted in Nunan, 2003: 193-194).

As the students were required to get quite a high level of language learning at the end of the first academic year, they were expected to invest time and effort in some aspects of language learning more than others. The students' judgment on different aspects of knowledge and skills are presented in Table 1 below.

Table 1: Learners' priority of language aspects

\begin{tabular}{lllllll}
\hline (most $=>$ least prioritized : 1-6) & Vocabulary & Grammar & Listening & Speaking & Reading & Writing \\
Mean & 3.7 & 4.5 & 3.4 & 2.6 & 4.2 & 3.0 \\
\hline
\end{tabular}

As can be seen in Table 1, productive skills tended to receive the most students' attention, with the Means of 2.6 and 3.0 respectively. On the other hand, the students seemed not to pay much attention to studying grammar whose Mean was 4.5. This was confirmed by Kim's answer to the interview: "at secondary school we learned a lot about grammar in the extra courses and I'm quite good at it so at high school we just focus on practising tests" (Interview 1). Similarly, reading also ranked as the second least urgent to most of them with the Mean of 4.2.

However much they tried to produce the language, a considerable number of students were possibly disappointed with the results they received. This can be interpreted from the students' ranking of their progress in language learning in Table 2 below.

Table 2: Student's evaluation of their language learning progress

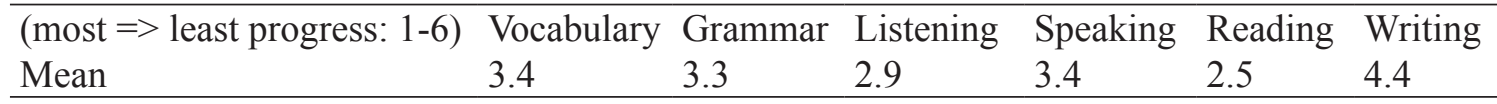

As we can see, receptive language skills like listening and reading (whose Means of progress were 2.9 and 2.5 respectively) appeared to be perceived as marking the most progress in classroom practices. In contrast, writing was generally regarded as the most difficult skill to master as it was almost ranked as the second least progress the students could make. This perception tends to go in lines with their feedback on the effectiveness of the classroom activities as presented in Chart 1 hereafter. 


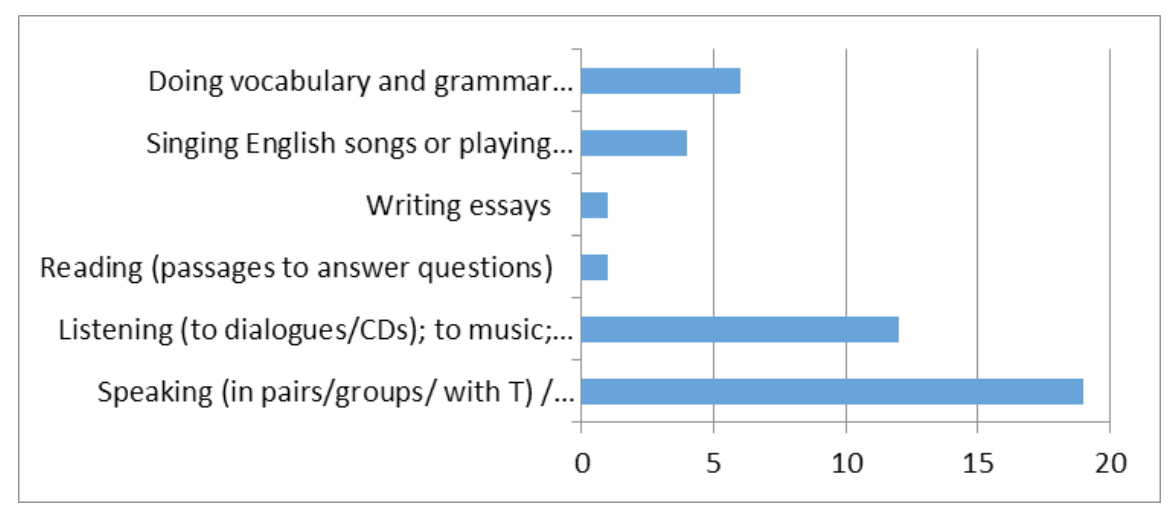

Chart 1: Students' evaluation of the most effective classroom activities

Chart 1 shows that students found they gained the best in speaking activities like discussing with classmates and the teacher in pairs/groups, as they answered Questionnaire 2 "this shows solidarity and chances to help one another; helps me to improve my weak skills; improves both my listening and speaking skills; gives me chances to get knowledge from friends; urges me to catch up with friends and work more seriously; reduces my inferior complexity and makes me more confident".

As to listening, 12 students explicitly stated that they saw listening activities the most effective because they help improve their listening skills and the content of the talks is interesting. They also take the opportunities to get used to the intonation of native speakers and increase their vocabulary. A student specifically mentioned her preference for English songs as this was the time she paid the greatest attention to the matter.

By contrast, only a small number of students (6) found their autonomy in self-study or doing the exercises in the coursebooks, reasoning that this helps them "improve their language easily and increase their selfregulation."

The most effective activities to the students were also the most difficult as presented in Chart 2.

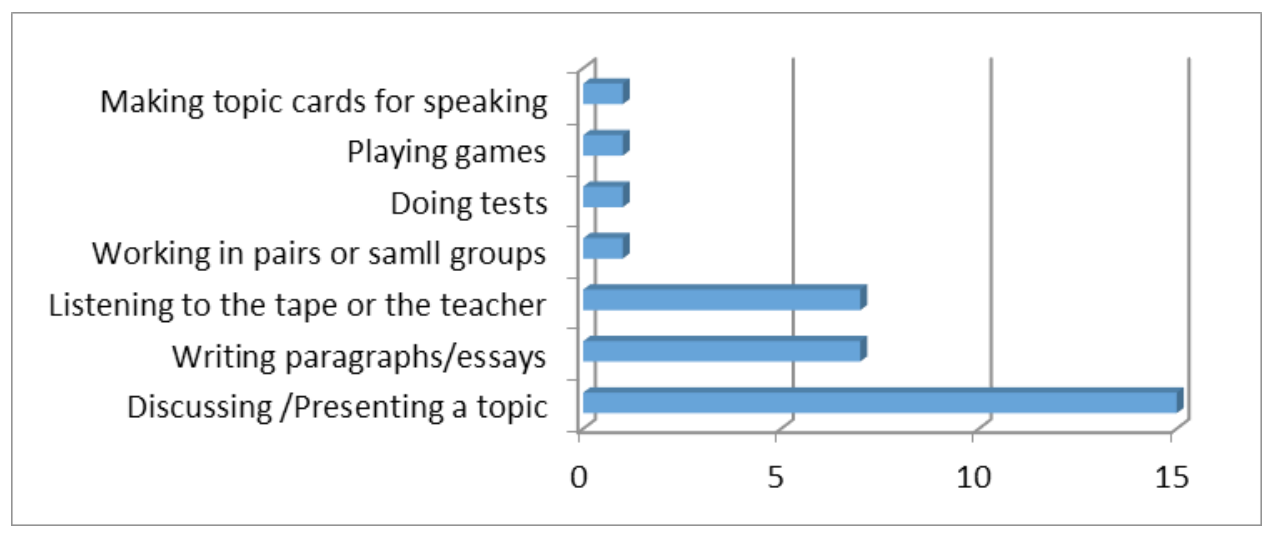

Chart 2: Students' evaluation of the most difficult classroom activities 
This chart reveals that while a large number of students (19) found speaking the most effective, an equally considerable number (15) said that they had trouble practicing it in class due to their "lack of vocabulary, poor pronunciation, being unconfident, and lack of sub-skills" (Questionnaire 2). Similarly, 7 students believed that writing was the most difficult for them due to their insufficient vocabulary and grammar knowledge. An equal number of students also found listening (including listening to the teacher) troublesome for the same reasons. Particularly, one student wrote, "I can hear just a little bit, feeling not wanting to learn."

\subsubsection{Learner expectation to control their} learning processes and resources in class

The second part of the questionnaires highlights the learners' desire to be involved in planning and managing their language learning processes, materials and classroom environment. These questions highlight "the right of learners to determine the direction of their own learning" (Benson \& Voller, 1997: 1 - 2, quoted in Nunan, 2003: 193-194).

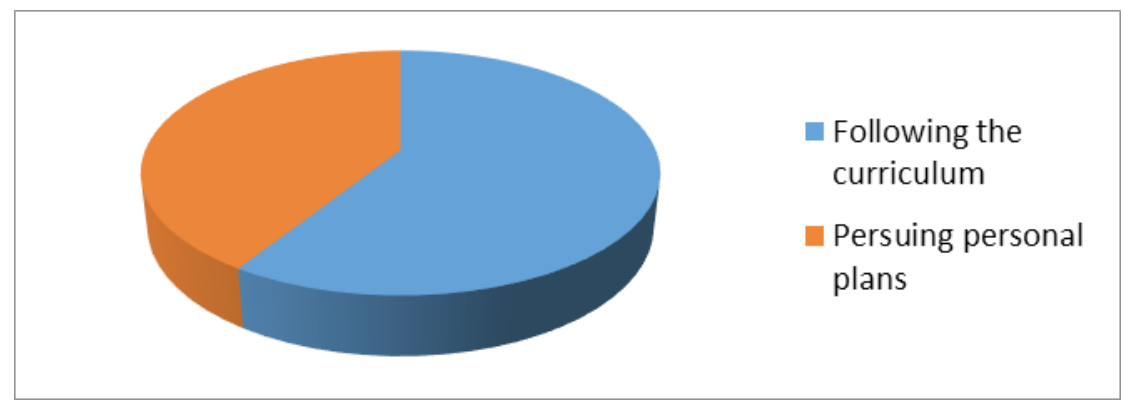

Chart 3: Learners' desire to follow their personal study plans

When asked whether they wanted to keep following the institution's language learning curriculum or pursuing their personal study plans, over half of the students (59\%) said that they wanted to study with others (of either lower or higher levels) and nearly half (41\%) wanted to completely taking charge of their study.

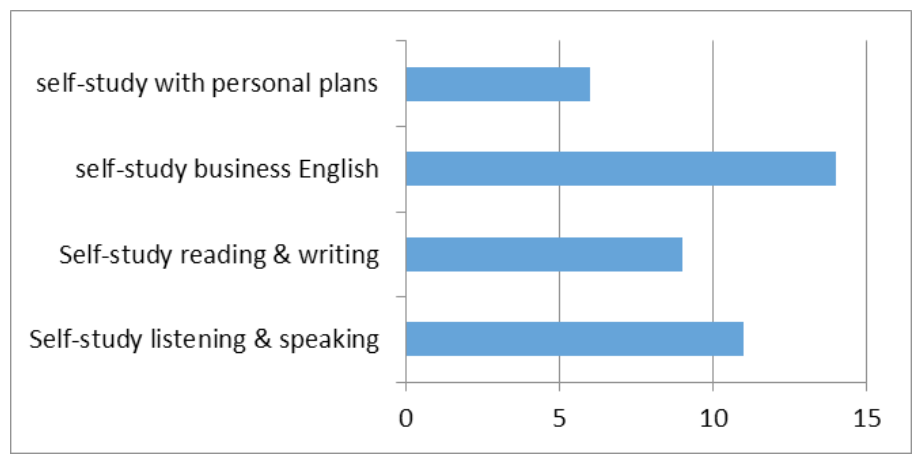

Chart 4: Learners' preference for self-study programmes 
Chart 4 presents the number of students showing preference for self-study programmes. They wanted to strengthen their language skills like listening and speaking (11 students) and reading and writing (9 students). Others (14) said that they wanted to study Business English or they had their own plans for learning English (6 students). Such plans were specified in their answers to the questionnaire as "writing essays, following the teacher's guide, improving their own four skills with 2-3 reading passages and 1 Business English text, writing an essay or a report every day to present in front of the class for the teacher to comment." For those who wanted to follow the school curriculum, they also wanted to add the activities of going out and communicating with foreigners to the schedule as one wrote in the questionnaire. This is partly shown in their preference for their initiation, activity types and partners in Chart 5 hereafter.

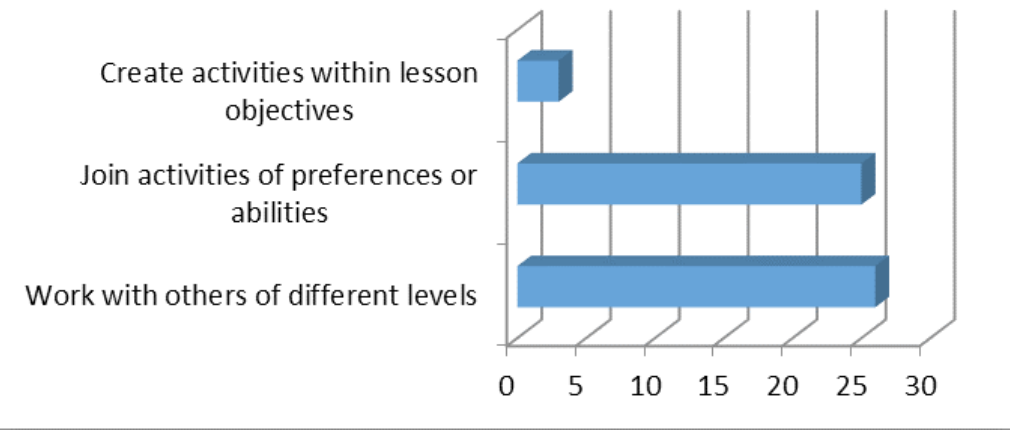

Chart 5: Learners' control of content and environment

As presented in Chart 5, even choosing to follow the school curriculum, the learners also showed their preference to exercise their control over the pair/group work activities including working with other learners of higher or lower language levels and according to their preferences and abilities (25-26 students said so). Importantly, 3 students even stated that they could create language learning activities following the lesson objectives.

Table 3: Students' taking online and/or extra English courses
4.2. Learner control over language learning processes, resources, and out-of-class language using contexts

Part of the first questionnaire also attempts to find out learners' learning activities outside the classroom and their attitudes towards possible learning resources available, as shown in Table 3.

Semester 1: Number

students took online courses 3

students took extra English courses 15

students wanted an online account 26 
In the first semester, the number of students who took online courses was very small: only three students. Those who were taking courses at an English center made a triple number of this one. Among these students, their favourite English learning activity was communicating with foreigners in communicative English courses where they found their progress in communication. In the second questionnaire, two students also emphasized that they took English courses with foreign teachers so that they could communicate in English only.

Twenty-six participants showed their willingness to pay 100,000VND for the English Department's online account. The reasons mentioned by them in the questionnaire were their poor communicative skills and needs for help in practice, their view of its necessity and usefulness and even their spare time for having not taken an extra course.

On the other hand, 34 students refused to buy this online account because they "did not have time and could not arrange time for studying online; they already took courses at English centers, found this not necessary and were not sure of its effectiveness."

The students also sought for opportunities to be exposed to and use the target language as revealed in the second questionnaire and the in-depth interviews. As to the way they learn English outside school, four students wrote that they often listened to music and watched videos, films and news in English.

Five other students mentioned that they sought for opportunities to use English in real life by talking with customers in their parttime jobs and with foreign exchange students in a volunteer programme and foreign visitors in opportunities created by themselves. A student told us about her practice of English in her part-time job below.
"I meet her [my colleague] about once a week and we speak in English whenever there are no customers. We talk about girl-related problems, our work, our future, challenges in life, outing, life skills, etc. - everything in English. She teaches me a lot about life skills and communicative skills like not showing your sad face when working out or even when feeling tired at work. She also teaches me how to answer customers, how to arrange goods according to production dates and expiry dates, which I did not notice. But we can speak in English only when there are no customers." (Interview 3, Anh)

Another student has experienced talking with foreign exchange students in several chances:

"When I was in grade 6 or 7, there was a student exchange programme and my sister invited a foreign student to stay in my house for about 1 month. Whenever I learned a new word I'd talk with her. I was not afraid of talking with foreigners. I just say out my thought. [...] And then for two weeks at the beginning of this semester, I also joined the volunteer groups to help foreign students going around in their programmes of donating books to Vietnamese schools. We had difficulty understanding each other at first but then things were okay. We still keep contact now." (Interview 1, Kim)

Some other students seek for opportunities to use English in real life communication themselves by going to places (like Ta Hien street as mentioned by a student) where there are foreign visitors. For instance, Tan told us in the interview, "I join events with groups of foreigners and Vietnamese students who are good at English: having dinner, talking, and traveling around Hoan Kiem lake." 


\section{Discussion}

Despite as the fact that some students seem to lay the locus (i.e. place) of control on the teacher, a considerable number of students do show their high level of autonomy in controlling their learning process, content and environment by organising their (class and self) learning activities, seeking language learning resources on the Internet and in real life, and creating opportunities to use the target language in places where English speaking people are available.

Such willingness to take responsibility for their own learning is a typical feature of learner autonomy as mentioned by Sinclair (2000, quoted in Borg, 2012: 5). This can be seen in a student's willingness to be the teacher assistant when she approached the teacher after the lesson the other day. She said, "I can be your assistant. I can help you teach the vocabulary. I think it's most important to learn new words in a foreign language. You know, I'm working part-time as a teacher assistant at an English center". This example can also be regarded as an indicator of the student's intrinsic motivation for life-long learning (Nguyễn Thị Hằng Nga \& Nguyễn Ngọc Toàn, 2017).

Additionally, this student shows two typical features of an autonomous language learner, that is the ability to control their own [as well as the class'] learning process (Holec, 1981; Little, 2009: 223) and the capability of critical reflection and initiation of change (Little, 1991; Little, 2009). Specifically, the learner's offer to help the teacher teach new words to the class also shows his/her ability to carry out management tasks like identifying the aim of vocabulary learning, having ideas of what words are necessary, choosing an appropriate teaching approach as well as evaluating the effectiveness of the teacher's instruction (Holec, 1981: 3, quoted in Lewis \& Vialleton, 2011: 206).
However, the number of such autonomous learners is not very big. Among them, only one student, who often spoke English with her Vietnamese co-worker in the part-time job, often showed attention in the lesson and took classroom learning seriously. The other two students who appeared to actively seek opportunities to communicate with foreigners outside school were sometimes off tasks in the class. Such a reality proves that "complete autonomy is an idealistic goal" and that "the degrees of autonomy are unstable and variable" (Sinclair, 2000, quoted in Borg, 2012, 5).

Looking more closely at the stories told by the students, we can see that autonomy comes as a result of both their will and luck, i.e. "autonomy has a social as well as an individual dimension" (Sinclair, 2000, quoted in Borg, 2012, 5). Tan was first introduced to a social meeting event with foreigners in his neighbourhood by his close friend who knew that his English was good enough (as he studied in English in Sweden from grade 3 to grade 7) to socialize with them throughout the evening. Then he made friends with a number of people there and kept meeting them during such social events till now. As for Kim, thanks to her active sister who took a foreign student home in an exchange programme, she had opportunities to communicate with that student and still kept contact with her at the time of the interview. Her university also brought her another chance to work with foreign exchange students for two weeks. Lastly, in Anh's case, she got the part-time job by chance and met her co-worker there who initiated to keep practising English in order not to forget her English.

In general, throughout a year learning English at school, the number of students clearly showing their high level of autonomy seems not to meet expectation. Nevertheless, "the Western style of autonomy based on language teaching cannot suit the learning style of each student" (Egel, 2009: 2024). 
Students' preference to follow the teacher's teaching plans and assignments does not mean that they are weak or unfavoured learners.

\section{Conclusion}

In this study, we explored the levels of autonomy in terms of learners' control over their language learning process, resources and contexts both inside and outside the classroom. The results of the study reveal that learners do "become more autonomous in language learning in proportion as they become more autonomous in language use, and vice versa" (Little, 1991, cited in Little, 2009). Nevertheless, the learner's degree of autonomy is not constant throughout different language learning contexts in and out of the classroom. In addition, learner autonomy cannot simply be built by giving them chances to control their own learning; it is the complex combination of learner's motivation, investment of money, time and effort and the social situation. In some cases, with low level language learners, for example, "the inability to control [many aspects of the situation in language learning] does not make either [the teacher or the learner] less autonomous" (Lewis \& Vialleton, 2011: 218). Such complexity leaves land for further investigation to enrich our knowledge in this aspect of language learning.

As for practitioners, though this study presents some specific examples of learners being very active to use English outside the classroom, it also shows a number of students who may be silent in class. This tends to suggest that some students prefer language using to "official" language learning. Thus, the teacher should create opportunities for learners to use the language by themselves and contribute to the autonomous community of classroom as suggested below.

\section{Recommendation - classroom as an autonomous learning community}

The idea of building the classroom as an autonomous learning community addresses "the importance of developing learner autonomy within the classroom through the support of the teachers and collaboration of the learners" on the basis that "learners are able to develop cognitive skills for their learning by being provided the opportunities to make decisions within the classroom" (Egel, 2009: 2024). It should follow three key principles: (1) learner involvement in planning, monitoring and evaluating their own learning, (2) learner continual reflection on the process and content of their learning and to engage in regular self-assessment, and (3) target language use: the target language as the medium as well as the goal of learning, including its reflective component (Little, 2001, cited in Little, 2009: 224). These can be specified as three main steps in developing learner autonomy: raising awareness, changing attitudes, and transferring roles (Scharle \& Szabó, 2000).

First, learners should be aware of the pedagogical goals and content of the materials they are using (Nunan, 1997). The questionnaires in this study were an example of helping learners reflect on their own learning process. Moreover, in the first classroom meeting, the students were informed of the course objectives and coursebooks. Then, they were divided into groups according to their language levels through a placement test on vocabulary, grammar, reading, and listening as well as a short speaking test. This is to prepare them for the second level of learner involvement in selecting their own goals from a range of alternatives on offer as suggested by Nunan (1997). In fact, at the beginning of each lesson, we presented its aims and correspondent activities of different levels of difficulties such as writing an advertisement of their house basing 
on the sample texts in the book or video taping their recommendation of a real hotel nearby for a conference. By giving learners choices like this, we expected that they would recognize of message of promoting their autonomy, and thus change their learning attitudes from being passive to more active, and proactive.

Then, the teacher should direct students' attitudes in terms of motivation, learning strategies, community building and selfmornitoring towards (Scharle \& Szabó, 2000) a higher level of autonomy, namely "intervention" (Nunan, 1997). At this levels, learners should be involved in modifying and adapting the goals and content of the learning program. As can be seen in this study, once the students are aware of their strengths and weakenesses as well as their own learning priorities as raised in the questionnaires, the learners could change the objectives of each specific task they choose to match their own learning goals and preferences.

The last step refers to transferring roles. In Nunan's (1997) words, learners should reach the last two levels of learners' creation of their own goals and objectives and transcendence: learners' going beyond the classroom and making links between the content of classroom learning and the world beyond. This can be seen in the case of the student approaching the teacher offerring to help teaching vocabulary or the case of the student initiating a talk with the teaching in English, telling her story of communicating with her co-worker in this language.

By taking the role of a researcher and adviser for their learners, teachers can build an autonomous learning classroom in which learners can build their habit of taking control over their own learning and seek for opportunities to learn beyond the school as one student responded in the questionnaire: "learning English is my habit, and I love it."

\section{Acknowledgements}

I am sincerely grateful to the reviewers and editors for their great tolerance, valuable comments and encouraging support for the improvement of this paper. Furthermore, I would like to thank all my students for their time and participation in making this study possible.

\section{References}

\section{Vietnamese}

Lưu Ngọc Lan (2014). Sử dụng các phương pháp tạo động lực trong lớp học tiếng Anh xã hội dạy kết hợp4 kĩ năng nghe, nói, đọc, viết. Trường Đại học Hà Nội. Kỷ yếu hội thảo khoa học quốc tế Chiến luợc ngoại ngũ trong xu thế hội nhập, 107-120.

Nguyễn Thị Hằng Nga, Nguyễn Ngọc Toàn (2017). "Không gậy, không kẹo" (xây dựng thói quen học tập với động lực nội sinh GIVE). Tạp chí Nghiên cứu Nước ngoài, 1(1), 89-101.

Nguyễn Thị Hằng Nga, Nguyễn Thị Hợp, Nguyễn Ngọc Toàn (2018). Quản trị bằng mục tiêu để khơi nguồndopamine nội sinh, gia tăng hứng thú học tập. Trường Đại học Ngoại ngữ - Đại học Quốc gia Hà Nội. Kỷ yếu hội thảo quốc gia 2018: Nghiên cưu và giảng dạy ngoại ngũu, ngôn ngũ \& quốc tế học tại Việt Nam, 409-415.

Đinh Thị Hồng Thu (2017). Tình hình tự chủ trong học tập của sinh viên khoa Ngôn ngữ và văn hóa Trung Quốc Trường Đại học Ngoại ngữ - Đại học Quốc gia Hà Nội. Kỷ yếu Hội thảo khoa học quốc gia 2017: Nghiên cúu và giảng dạy ngoại ngũu, ngôn ngũ \& quốc tế học tại Việt Nam, 347-355.

\section{English}

Benson, P. (1996). Concepts of autonomy in language learning. In R. Pemberton, E. Li, W. Or and

H. Pierson, (Eds.), Taking control: Autonomy in language learning (pp. 27-34). Hong Kong: Hong Kong University Press.

Benson, P. (1997). The philosophy and politics of learner autonomy. In I. Benson \& P. Voller (Eds.), Autonomy and independence in language learning. London: Longman.

Benson, P. \& Voller, P. (1997). Introduction: autonomy and independence in language learning. In P. Benson and P. Voller (Eds.), Autonomy and independence in language learning. Harlow: Longman.

Benson, P. (2001). Teaching and researching autonomy in language learning. Harlow: Pearson.

Benson, P. (2003). Learner autonomy in the classroom. In Nunan, D. (Ed.), Practical English language teaching. New York: McGraw Hill. 
Benson, P., Chik, A. \& Lim, H. (2003). Becoming autonomous in an Asian context: Autonomy as a sociocultural process. In D. Palfreyman, \& R. C. Smith (Eds.), Learner autonomyacross cultures: Language education perspectives (pp. 23-40). New York: Palgrave Macmillan.

Borg, S. (2012). Leaner autonomy: English language teachers' beliefs and practices. London: British Council.

Boud, D. (1981). Moving towards autonomy. In D. Boud (Ed.), Developing student autonomy in learning. London: Kogan Page.

Brookfield, S. D. (1986). Understanding and facilitating adult learning. San Francisco: Jossey-Bass.

Brookfield, S. D. (1990). The skillful teacher. Sanf Francisco. Jossey-Bass Publishers.

Ceylan, N. O. (2015). Fostering learner autonomy. Procedia - Social and Behavioral Sciences, 199, 85-93.

Dickinson, L. (1987). Self-instruction in language learning. Cambridge: Cambridge University Press.

Egel, I. P. (2009). Learner autonomy in the language classroom: from teacher dependency to learner independency. Procedia Social and Behavioural Sciences, 1, 2023-2026.

Farivar, A., \& Rahimi, A. (2015). The impact of CALL on Iranian EFL learners' autonomy. Procedia Social and Behavioral Sciences, 192, 644-649.

Gillham, B. (2000a). Developing a questionnaire. London: Continuum.

Gillham, B. (2000b). Developing an interview. London: Continuum.

Holec, H. (1981). Autonomy and foreign language learning. Oxford: Pergamon.

Ismail, N., \& Yusof, M. A. M. D. (2012). Using language learning contracts as a strategy to promote learner autonomy among ESL learners. Procedia Social and Behavioral Sciences, 66, 472-480.

Lewis, T., \& Vialleton, E. (2011). The notions of control and consciousness in learner autonomy and selfregulated learning: a comparison and critique. Innovation in Language Learning and Teaching, 5(2), 205-219.

Little, D. (1991). Learner autonomy 1: Definitions, issues, problems. Dublin: Authentik.

Little, D. (2009). Language learner autonomy and the European Language Portfolio: Two L2 English examples. Language Teaching, 42(2), 222-233.

Mackey, A. \& Gass, S. M. (2005). Second language research. Methodology and design. Mahwah, NY: Lawrence Erlbaum Associates.

Norton, B. (1995). Identity and language learning. Hong Kong: Pearson Education.

Norton, B., \& Toohey, K. (2002). Identity and language learning. In R. B. Kaplan(Ed.), The Oxford handbook of applied linguistics (pp. 115-116). Oxford: Oxford University Press.

Nunan, D. (1997). Designing and adapting materials to encourage learner autonomy. In P. Benson \& P.

Voller (Eds.), Autonomy and independence in languag learning (pp. 192-203). Harlow: Longman.

Nunan, D. (2001) (9th printing) /1992 (1st printing). Research methods in language learning. Cambridge, UK: Cambridge University Press.

Nunan, D. (2003). Nine steps to learner autonomy. Synpodium, 2003 (193-204). Available through $<$ http://www.su.se/polopoly fs/1.84007 $.1333707257 ! / \mathrm{menu} / \mathrm{standard} / \mathrm{file} / 2003 \_11$ Nunan_eng.pf>, Accessed 15/5/2019 09:33.

Oxford, R. L. (1990). Language learning strategies: What every teacher should know. Boston: Heinle \& Heinle.

Oxford, R. L. (2003). Toward a more systematic model of L2 learner autonomy. In D. Palfreyman, \& R. C. Smith (Eds.), Learner autonomy across cultures: Language education perspectives (pp. 75-91). New York: Palgrave Macmillan.

Palfreyman, D., \& Smith, R. C. (2003). Learner autonomy across cultures: Language education perspectives. New York: Palgrave Macmillan.

Richards, K. (2003). Qualitative inquiry in TESOL. New York: Palgrave MacMillan.

Scharle, Á., \& Szabó, A. (2000). Learner autonomy: A guide to developing learner responsibility. Cambridge: Cambridge University Press.

Sinclair, B. (2000). Learner autonomy: The next phase? In B. Sinclair, I. McGrath \& T. Lamb (Eds.), Learner autonomy, teacher autonomy: Future directions (pp. 4-14). Harlow: Longman.

Toohey, K., \& Norton, B. (2003). Learner autonomy as agency in sociocultural settings. In D. Palfreyman \& R. C. Smith (Eds.), Learner autonomy across cultures: Language education perspectives. (pp. 72). New York: Palgrave Macmillan.

Vela, V., \& Rushidi, J. (2016). The effect of keeping vocabulary notebooks on vocabulary acquisition and learner autonomy. Procedia - Social and Behavioral Sciences, 232, 201-208.

Vygotsky, L. S. (1978). Mind in society: The development of higher Psychological processes. Cambridge, MA: Havard University Press.

Wen, Q. (2004). Research methods and thesis writing. Beijing: Foreign Language Teaching and Research Press.

Xhaferi, B. \& Xhaferi, G. (2011). Developing learner autonomy in higher education in Macedonia. Procedia Social and Behavioral Sciences, 11, 150-154. 


\title{
TÍNH TỰ CHỦ CỦA NGƯỜI HỌC NGOẠI NGỮ VÃ CƠ HộI HỌC TẬP TRONG VÃ NGOÀI LỚP HỌC
}

\author{
Hoàng Nguyễn Thu Trang \\ Truờng Đại học Ngoại ngũu, ĐHQGHN, Phạm Văn Đồng, Cầu Giấy, Hà Nội, Việt Nam
}

Tóm tắt: Nghiên cứu này được thực hiện nhằm chỉ ra mức độ người học là sinh viên không chuyên năm thứ nhất thể hiện tính tự giác trong đánh giá và quản lý quá trình học tập, nguồn lực và môi trường học ngoại ngữ trong và ngoài lớp. Dữ liệu được thu thập từ bảng hỏi với 63 sinh viên, phỏng vấn bán cấu trúc (trong vòng 30-60 phút) và ghi chép quan sát của người dạy trong các tiết học. Kết quả thống kê để tìm giá trị trung bình và tần xuất và phân tích nội dung để tìm điểm chung trong dữ liệu này cho thấy mức độ kiểm soát của các sinh viên cũng như mỗi sinh viên đối với quá trình và tài liệu học tập trong các môi trường học khác nhau là không giống nhau. Điều này thể hiện tầm quan trọng của việc giúp người học kiến tạo cơ hội học tập trong và ngoài lớp học.

Tù khóa: tính tự chủ, quá trình học tập, nguồn lực học tập, môi trường học tập 